\title{
A Low Temperature Manufactured Portland Cement Clinker from Pulverized Waste of Fly Ash
}

\author{
Hassan Hassanien Mohamed Darweesh \\ Refractories, Ceramics and Building Materials Department, National Research Centre, Cairo, Egypt
}

Email address:

hassandarweesh2000@yahoo.com

\section{To cite this article:}

Hassan Hassanien Mohamed Darweesh. A Low Temperature Manufactured Portland Cement Clinker from Pulverized Waste of Fly Ash. International Journal of Materials Science and Applications. Vol. 9, No. 2, 2020, pp. 34-39. doi: 10.11648/j.ijmsa.20200902.12

Received: April 21, 2020; Accepted: May 18, 2020; Published: June 28, 2020

\begin{abstract}
The possibility to produce both environmentally and friendly cement exclusively or solely from industrial byproducts such as pulverized fly ash $(\mathrm{PFa})$ was investigated. A low clinkering temperature was attained or acquired to produce cement. It is capable to gain high early and late strength on hydration. The optimum quantities of PFa and clinkering temperature were detected. The results indicated that the higher the clinkering temperature, the higher hydration reactivity of the cement. The optimum PFa content and clinkering temperature for synthesizing cement were found to be 35 wt. $\%$ and $1350^{\circ} \mathrm{C}$, respectively. The production of cement with $\mathrm{PFa}$ at a low clinkering temperature can save energy and natural resources consumption, landfills disposal cost and also can reduce $\mathrm{CO}_{2} \uparrow$ emission. The formed major phases in presence of $\mathrm{PFa}$ are more or less the same as those of the blank as experimentally achieved and approved by the compressive strength. As the PFa content increased, the free lime contents decreased, and also the firing or clinkering temperature decreased. The optimum PFa content must not exceed than $35 \mathrm{wt}$ \%, and any further increase of Pfa resulted in adverse effects on all characteristics of the produced clinker.
\end{abstract}

Keywords: Cement, Fly Ash, Clinkering Temperature, Phases, Hydration, Free Lime, Strength, XRF

\section{Introduction}

\subsection{Scope of the Study}

There is no doubt that the problem of solid wastes is spreading all over the world so that this creates the need to exploit and/or reutilize these solid wastes in useful applications. The pulverized fly ash (PFa) from coal combustion that fired in the thermal power plants is one of such solid wastes. PFa could be obtained by the electrostatic or mechanical precipitation of dust-like particles from the flue gases inside furnaces using coal or lignite at 1100$1400^{\circ} \mathrm{C}$. $\mathrm{PFa}$ is a fine powder that is mainly composed of spherical glassy particles of silica and depending upon the types of boiler and coal, siliceous, silico-calcareous and calcareous fly ashes with pozzolanic reactivity are produced [1-3]. Fly ash is mostly used as a pozzolanic additive in the cement and/or concrete. However, fly ash may be used for other purposes such as traditional ceramics, glass ceramics [4], as the material for land consolidation in road construction [4-8], land stabilization in mining areas [6], sorbents for the flue gas desulphurization [7], a filling material in making various products [8], and synthesis of zeolites [6-10].

Many authors investigated fly ash to determine its suitability for application in the cement and concrete industry [11-14], as lightweight aggregate [15, 16], as a replacement for cement, mortar and/or concrete [17-21]. Each of these applications requires a complete characterization of the fly ash involved. Although application of fly ash as the cement raw material has been reported, only few articles refer to it as a cement raw feed component $[1,4,6,10]$.

\subsection{Environmental Impacts}

The manufacture of Portland cement can cause environmental impacts at all stages of the process including emissions of airborne pollution in the form of dust, gases, noise and vibration when it is operating machinery and during blasting in quarries, consumption of large quantities of fuel during manufacture, release of carbon dioxide $\left(\mathrm{CO}_{2} \uparrow\right)$ from the exposure in Portland cement plants, from the centers for disease control, states that "Workers at Portland cement 
facilities, particularly those burning fuel containing sulfur, should be aware of the acute and chronic effects of exposure to $\mathrm{SO}_{2} \uparrow$, and peak and full-shift concentrations of $\mathrm{SO}_{2} \uparrow$ should be periodically measured $[1,7,9,16]$.

Further reduction of energy consumption and $\mathrm{CO}_{2} \uparrow$ emissions could be achieved by using waste materials containing $\mathrm{CaO}$ more than $\mathrm{CaCO}_{3}$, thereby in turn a further reduction in the environmental impact. Waste materials suitable for achieving these targets include lime dust, fly ash and granulated blast furnace slag for their high $\mathrm{CaO}, \mathrm{Al}_{2} \mathrm{O}_{3}$, and $\mathrm{SO}_{3}$ contents rather than $\mathrm{CaCO}_{3}[10,22-25]$.

\subsection{Objectives of the Study}

It is well known that the production of Portland cement is now very expensive and therefore the current study aims to determine whether pulverized fly ash ( $\mathrm{PFa}$ ) can be utilized as a component in the raw meal for the production of Portland cement clinker or not. So, it can be used as an alternative component in cement industry. Chemical and mineralogical compositions of the produced Portland fly ash cement clinkers have been performed to know the possibility of its application as a raw material in the construction industry compared with the pure Portland cement clinker. Primarily in the production of Portland cement clinker, the X-ray florescence (XRF) of the produced clinker were done to identify the synthesis and the formed phases comparing to those of the plank sample.

\section{Experimental and Methods}

\subsection{Raw Materials}

The raw materials are clay (TCY), limestone (SLS) and pulverized fly ash (PFa). The TCY sample was taken from Toshka area that is located on latitude $20^{\circ} 30^{-} \mathrm{N}$ and longitude $31^{\circ} 53^{-} \mathrm{E}$ at $250 \mathrm{~km}$ south of Aswan, Egypt. It was related to the Upper Cretaceous age. The selected TCY deposit is belonging to El-Dakhla Shale Formation. About 20 $\mathrm{kg}$ TCY was collected from the $85^{\text {th }} \mathrm{km}$ north of Aswan/Abusumple asphaltic road. It is a dark yellowish grey. The TCY sample was first dried at $105^{\circ} \mathrm{C}$ for 3 days at a suitable dryer, and then crushed using a suitable crusher, ground and quartered to have a representative sample to pass a 200 mesh sieve. The SLS sample taken from Samalout district, was supplied by the Arab Ceramic Company (Aracemco). The PFa sample was obtained from Egyptian Local plant, which in turn was obtained from abroad has a grain size of about $\approx$ $63 \mu \mathrm{m}$. The clay, limestone and pulverized fly ash are respectively given the symbol TCY, SLS and PFa as shown above. The chemical composition of these raw materials, which was achieved classically by normal chemical analysis according to ASTM Standards [26, 27] is shown in Table 1. The mineral composition of $\mathrm{PFa}$ specimen was investigated by X-ray diffraction patterns (XRD) and diffration thermal analysis (DTA). The XRD analysis was achieved by a Phillips X-ray diffractometer (XRD), PW 1710 powder with an anticathode copper radiation and $\mathrm{Cu}-\mathrm{K} \alpha$ radiation, wavelength of $1.54178 \AA$ and a graphite monochromator. The tube working voltage was $40 \mathrm{kV}$ and current strength was 30 $\mathrm{mA}$, in the range $5-50^{\circ} 2 \theta$ with a step of 0.02 and 0.5 seconds retention time for each step, while the DTA analysis was carried out using NETZSCH Geratobau Selb, Bestell-Nr. $348472 \mathrm{c}$ at a heating rate $10^{\circ} \mathrm{C} / \mathrm{min}$ up to $1000^{\circ} \mathrm{C}$.

\subsection{Preparation of Cement Pastes}

The base batch of PC clinker was prepared from 25 wt. \% TCY and 75 wt. \% SLS and was given the symbol (F0). The base batch (F0) was replaced by $0,5,15,25,35$ and 45 wt. \% of PFa, where the mixes are taken the symbols F0, F1, F2, F3, F4 and F5, respectively as shown in Table 2.

Table 1. Chemical composition of the starting rea materials, $\%$.

\begin{tabular}{|c|c|c|c|c|c|c|c|c|c|c|c|c|}
\hline Oxide Material & LOI & $\mathrm{SiO}_{2}$ & $\mathbf{A l}_{2} \mathbf{O}_{3}$ & $\mathrm{Fe}_{2} \mathrm{O}_{3}$ & $\mathrm{CaO}$ & MgO & $\mathrm{Na}_{2} \mathrm{O}$ & $\mathrm{K}_{2} \mathrm{O}$ & $\mathrm{SO}_{3}$ & $\mathrm{TiO}_{2}$ & $\mathbf{P}_{2} \mathrm{O}_{5}$ & Cl \\
\hline TCY & 9.72 & 53.47 & 26.78 & 3.99 & 0.63 & 1.38 & 1.15 & 1.18 & ---- & 1.12 & 0.51 & $\begin{array}{l}--- \\
--\end{array}$ \\
\hline SLS & 42.63 & 0.08 & 0.03 & 0.04 & 56.84 & 0.10 & 0.12 & 0.05 & 0.02 & 0.01 & ---- & 0.08 \\
\hline $\mathrm{PFa}$ & 2.32 & 60.13 & 21.94 & 5.82 & 6.23 & 0.15 & 0.18 & 0.98 & 1.35 & ---- & ---- & ---- \\
\hline
\end{tabular}

Table 2. Batch composition of Portland cement clinker and its finenesses, $w t \%$.

\begin{tabular}{lllll}
\hline Material Batch & TCY & SLS & PFa & Fineness, $\mathbf{c m}^{\mathbf{2}} \mathbf{g}$ \\
\hline P0 & 25 & 75 & --- & 3350 \\
P1 & 25 & 70 & 5 & 3640 \\
P2 & 25 & 65 & 15 & 3850 \\
P3 & 25 & 60 & 25 & 4125 \\
P4 & 25 & 55 & 35 & 4465 \\
P5 & 25 & 50 & 45 & 4640 \\
\hline
\end{tabular}

\subsection{Test Methods}

It is well known that the Portland cement clinker (PCC) is always manufactured in a rotary kiln starting from the atmosphere temperature up to $1450^{\circ} \mathrm{C}$. The various forms of PC clinkers mixed with $\mathrm{PFa}$ (F0-F5) produced at their optimum firing temperatures $\left(1410-1280^{\circ} \mathrm{C}\right)$, respectively were subjected to X-ray florescence (XRF) in order to identify their oxide composition. After the formation of the different clinkers, all are subjected to chemical analysis to identify the free lime and the insoluble residue in each clinker to detect the unreacted silica and other materials during firing [26]. Then, the phase compositions of each clinker could be calculated from Bogue equations [21, 24, 28] as follows:

$$
\mathrm{C}_{3} \mathrm{~S}, \%=4.07(\mathrm{CaO})-7.60\left(\mathrm{SiO}_{2}\right)-6.72\left(\mathrm{Al}_{2} \mathrm{O}_{3}\right)-1.43 \quad\left(\mathrm{Fe}_{2} \mathrm{O}_{3}\right)-2.85\left(\mathrm{SO}_{3}\right)
$$




$$
\begin{gathered}
\mathrm{C}_{3} \mathrm{~A}, \%=2.65\left(\mathrm{Al}_{2} \mathrm{O}_{3}\right)-1.69\left(\mathrm{Fe}_{2} \mathrm{O}_{3}\right) \\
\mathrm{C}_{4} \mathrm{AF}, \%=3.04\left(\mathrm{Fe}_{2} \mathrm{O}_{3}\right) \\
\beta-\mathrm{C}_{2} \mathrm{~S}, \%=2.87\left(\mathrm{SiO}_{2}\right)-0.754\left(\mathrm{C}_{3} \mathrm{~S}\right)
\end{gathered}
$$

In order to compare the quality of each type of the prepared clinkers, each of the prepared clinkers were mixed with 4 wt. \% raw gypsum $\left(\mathrm{CaSO}_{4} .2 \mathrm{H}_{2} \mathrm{O}\right)$ to prepare Ordinary Portland cement (OPC). Then, they were let to hydrate for 1, 3, 7, 28 and 90 days at which the compressive strength were measured to compare and select the optimum content of PFa in the cement. The compressive strength [29] was measured by using a hydraulic testing machine of the Type LPM 600 M1 SEIDNER (Germany) having a full capacity of $600 \mathrm{KN}$ and the loading was applied perpendicular to the direction of the upper surface of the cubes as follows:

$$
\mathrm{CS}=\mathrm{L}(\mathrm{KN}) / \mathrm{Sa}\left(\mathrm{cm}^{2}\right) \mathrm{KN} / \mathrm{m}^{2} \times 102\left(\mathrm{Kg} / \mathrm{cm}^{2}\right) / 10.2(\mathrm{MPa})(5)
$$

Where, CS: Compressive strength (MPa), L: load (KN), Sa: surface area $\left(\mathrm{cm}^{2}\right)$.

\section{Results and Discussion}

\subsection{Composition of the Used Raw Materials}

Table 1 indicates the chemical oxide composition of TCY and P PFa samples. The most important and basic oxides in the chemical composition of TCY and PFa samples are $\mathrm{SiO}_{2}$, $\mathrm{Al}_{2} \mathrm{O}_{3}, \mathrm{Fe}_{2} \mathrm{O}_{3}$ and $\mathrm{CaO}$ while the minor and less important oxides are $\mathrm{MgO}, \mathrm{MnO}, \mathrm{Na}_{2} \mathrm{O}, \mathrm{K}_{2} \mathrm{O}$ and $\mathrm{SO}_{3}$. Due to ASTM C618-05, 2005 [27], which is based on the sum of $\mathrm{SiO}_{2}$, $\mathrm{Al}_{2} \mathrm{O}_{3}$ and $\mathrm{Fe}_{2} \mathrm{O}_{3}$, the used $\mathrm{PFa}$ can be classified as a high calcium Fa. The sum of $\mathrm{SiO}_{2}, \mathrm{Al}_{2} \mathrm{O}_{3}$ and $\mathrm{Fe}_{2} \mathrm{O}_{3}$ in the used $\mathrm{Fa}$ sample is $85.66 \%$.

On the other side, the oxides of $\mathrm{Si}, \mathrm{Al}, \mathrm{Fe}$ and $\mathrm{Ca}$ are the vital and more important constituents of the raw mixture used for Portland cement clinker production. During firing or sintering of these oxides in the kiln, the clinker minerals are formed. These are calcium silicates $\left(\mathrm{C}_{3} \mathrm{~S}\right.$ and $\left.\beta-\mathrm{C}_{2} \mathrm{~S}\right)$, calcium aluminates $\left(\mathrm{C}_{3} \mathrm{~A}\right)$ and calcium aluminoferrites $\left(\mathrm{C}_{4} \mathrm{AF}\right)$. The $\mathrm{CaO}$ in the cement mixture is usually obtained from calcareous compound, such as limestone $\left(\mathrm{CaCO}_{3}\right)$, while the oxides of $\mathrm{Si}, \mathrm{Al}$ and $\mathrm{Fe}$ are obtained from an argillaceous compound such as clay. By its chemical composition of Fa sample is similar to TCY to a large extent, so it could be successfully used as a raw component in the raw meal during the manufacture of Portland cement clinker. According to the content of $\mathrm{SiO}_{2}$ in the used $\mathrm{Fa}$ sample, it can therefore lead to minimize the need to use other $\mathrm{SiO}_{2}$ carriers like sand or quartz. The chemical composition of the used $\mathrm{Fa}$ sample indicates the existence of all oxides we need in the main raw mixture components to produce Portland cement clinker. Table 1 also illustrates the analysis of the limestone which contains essentially $\mathrm{CaO}(56.84 \%)$ and traces from other oxides, while its loss on ignition was $42.63 \%$.

\subsection{XRD, DTA Analyses and SEM Image of PFa}

The XRD diffraction patterns of the used PFa sample are shown in Figure 1. Crystalline and amorphous phases are detected and also the differences in the amounts of amorphous phases. The crystalline phases were identified according to JCPDS standards. The content of any individual mineral phases cannot be easily identified. The PFa sample contains a significant amount of amorphous matter, but low amounts of crystalline phases, as quartz (Q) and feldspar (F). In most cases, hematite $(\mathrm{H})$, anhydrite $(\mathrm{A})$ and mullite $(\mathrm{M})$ are detected. The amorphous phase minerals are more reactive if it is compared to the crystalline phases. This confirms the exploitation of $\mathrm{PFa}$ as an alternative substitute for the normal raw mixture used to produce Portland cement clinker.

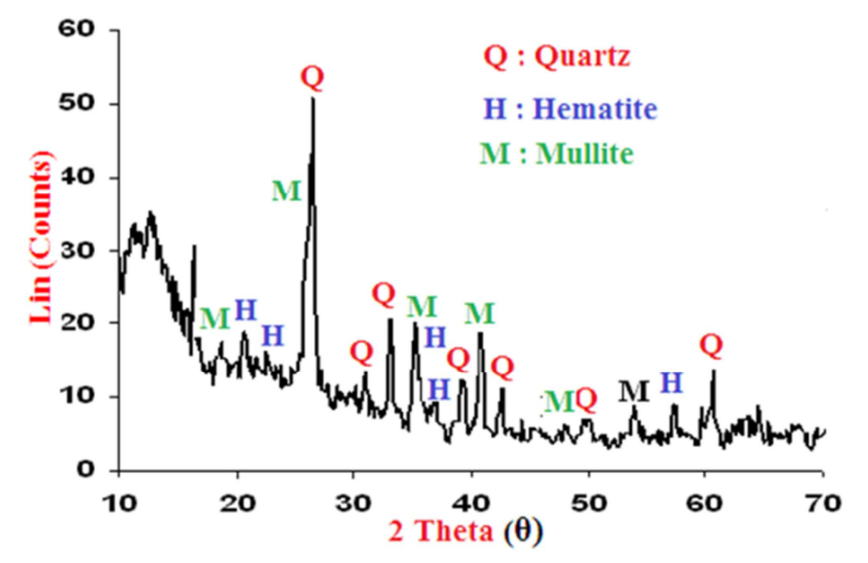

Figure 1. The XRD analysis of the used PFa sample.

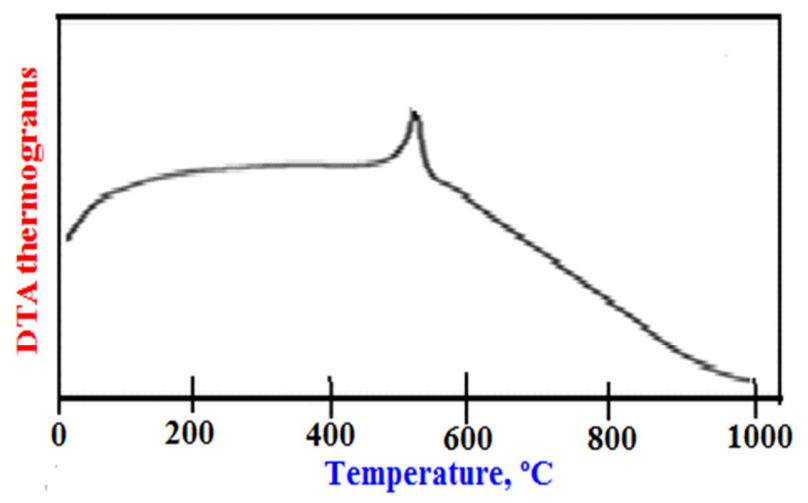

Figure 2. The DTA analysis of the used fly ash sample.

The DTA thermograms of PFa sample is shown in Figure 2. The exothermal peak at about $500-550^{\circ} \mathrm{C}$ proves that carbon does not burned completely. The existence of unburned carbon in PFa sample make it to be used successfully as a suitable raw material in the raw mixture, but with smaller amounts of fuel. Hence, it is in turn lead to the 
reduction of the energy needed for the sintering process [30]. The DTA curve of the studied PFa sample up to $1000^{\circ} \mathrm{C}$ did not show any other exo- and/or endothermic peaks that could eventually correspond to the formation of new mineral phases during heating and/or sintering. Figure 3 shows the microstructure of the $\mathrm{PFa}$ sample. There are several particulates with various shapes and sizes as flocculants or almost globulars.

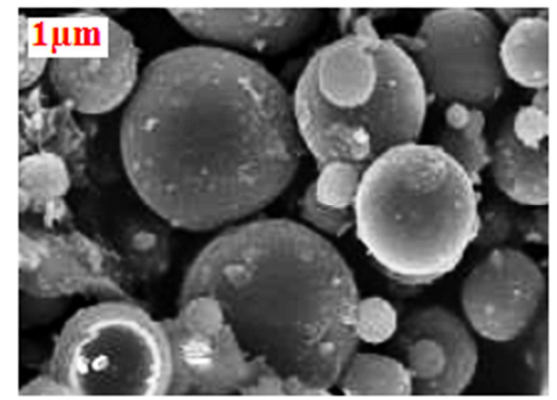

Figure 3. The SEM image of the used PFa sample.

\subsection{The XRF and Major Phases of the Formed Cement Clinkers}

Table 3 shows the X-ray florescence (XRF) of the resulting cement clinkers containing $\mathrm{PFa}$ (F0-F5). As it is clear, there are no significant differences in the amounts of the various oxide compositions. Also, the free lime content of the prepared clinkers (Figure 4) was slightly decreased. This is due to that the addition of $\mathrm{PFa}$ was at the expense of other main raw materials. On contrast, the insoluble residue was slightly increased due to the gradual increase of silica from $\mathrm{PFa}$. This means that the addition of PFa does not largely affect the main composition of the resulting cement clinkers if compared with the control (F0). Furthermore, the decrease of free lime content is an advantage because as the free lime increases the specific characteristics of the cement are adversely affected. On the other side, the increase of the insoluble residue in the cement is another advantage due to the improvement in the durability of the cement against several aggressive media [31-33].

Table 3. The XRF analysis of the produced cement clinkers.

\begin{tabular}{|c|c|c|c|c|c|c|c|c|c|c|c|}
\hline & LOI & $\mathrm{SiO}_{2}$ & $\mathbf{A l}_{2} \mathbf{O}_{3}$ & $\mathrm{Fe}_{2} \mathrm{O}_{3}$ & $\mathrm{CaO}$ & MgO & $\mathrm{Na}_{2} \mathrm{O}$ & $\mathbf{K}_{2} \mathbf{O}$ & $\mathrm{SO}_{3}$ & Free lime & Insol. residue \\
\hline F0 & 23.2 & 21.51 & 6.03 & 4.12 & 64.08 & 0.68 & 0.21 & 0.11 & 1.39 & 1.12 & 1.26 \\
\hline $\mathrm{F} 1$ & 2.71 & 21.61 & 5.22 & 3.76 & 63.14 & 1.22 & 0.17 & 0.09 & 2.39 & 1.10 & 1.31 \\
\hline $\mathrm{F} 2$ & 2.82 & 21.93 & 4.98 & 2.21 & 62.06 & 1.69 & 0.26 & 1.16 & 2.15 & 1.00 & 1.62 \\
\hline F3 & 2.64 & 21.81 & 4.71 & 2.88 & 61.63 & 1.53 & 0.51 & 0.32 & 2.42 & 0.96 & 1.78 \\
\hline F4 & 2.93 & 22.06 & 4.75 & 2.52 & 61.85 & 2.17 & 1.32 & 0.21 & 2.31 & 0.91 & 1.82 \\
\hline F5 & 3.08 & 21.76 & 4.69 & 2.83 & 61.18 & 1.28 & 0.26 & 0.13 & 2.21 & 0.87 & 1.96 \\
\hline
\end{tabular}

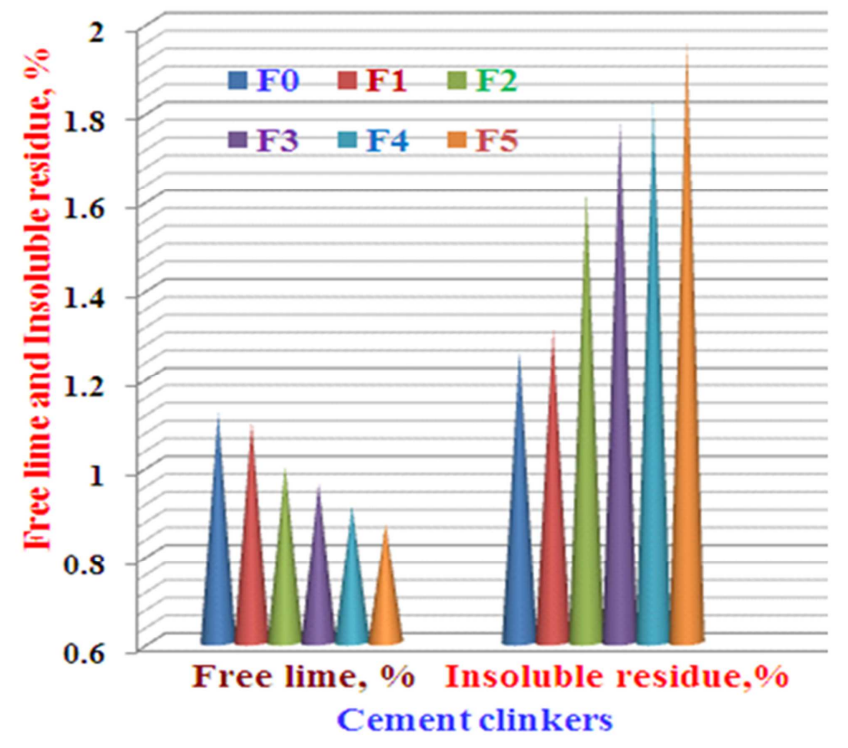

Figure 4. Free lime content and insoluble residue of the prepared cement clinkers.

The major four phases $\left(\mathrm{C}_{3} \mathrm{~S}, \beta-\mathrm{C}_{2} \mathrm{~S}, \mathrm{C}_{3} \mathrm{~A}\right.$ and $\left.\mathrm{C}_{4} \mathrm{AF}\right)$ of the various formed Portland cement clinkers containing different proportions of $\mathrm{PFa}$ (F0-F5) as calculated from Bogue Equations [24, 28] are listed in Table 4, and then are plotted in Figure 5. It is obvious that the percentage of $\mathrm{C}_{3} \mathrm{~S}$ is decreased with the increase of PFa content as shown in Table
4 and Figure 5. In contrast, the percentage of $\beta-\mathrm{C}_{2} \mathrm{~S}$ increased as the PFa content increased, except that of F4 which was little lower. However, all values of either $\mathrm{C}_{3} \mathrm{~S}$ and/or $\mathrm{C}_{2} \mathrm{~S}$ are very close or near to each other. This means that all mix composites are suitable to be exactly match to ASTM specifications [26]. The other two phases $\left(\mathrm{C}_{3} \mathrm{~A}\right.$ and $\left.\mathrm{C}_{4} \mathrm{AF}\right)$ are similar to those of the blank clinker sample (F0). It could be concluded that the PFa could be used as a raw meal in the starting raw mix of cement clinker in the ratio 25-35 wt. \% without any adverse effects.

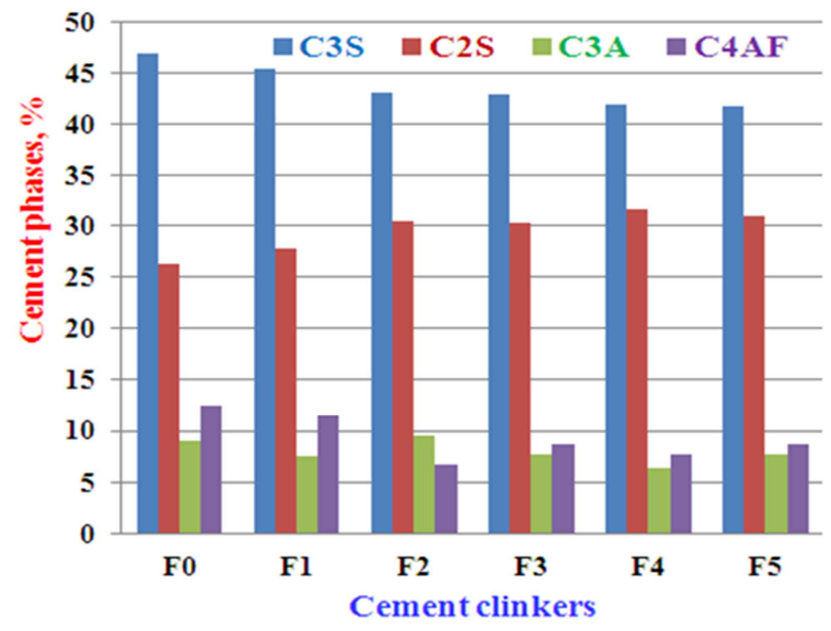

Figure 5. The major phases of the prepared Fa cement clinker. 
Table 4. The major cement phases of the resulting cement clinkers.

\begin{tabular}{llllll}
\hline Phase Mixes & $\mathbf{C}_{\mathbf{3}} \mathbf{S}$ & $\boldsymbol{\beta}-\mathbf{C}_{2} \mathbf{S}$ & $\mathbf{C}_{\mathbf{3}} \mathbf{A}$ & $\mathbf{C}_{4} \mathbf{A F}$ & Total \\
\hline F0 & 46.9549 & 26.3297 & 9.0167 & 12.5248 & 94.8261 \\
F1 & 45.4771 & 27.7310 & 7.4786 & 11.4304 & 92.1171 \\
F2 & 43.1628 & 30.3943 & 9.4621 & 6.7184 & 89.7376 \\
F3 & 42.9245 & 30.2296 & 7.6173 & 8.7552 & 89.5266 \\
F4 & 41.9664 & 31.6698 & 6.3287 & 7.6608 & 87.6257 \\
F5 & 41.7644 & 30.9068 & 7.6458 & 8.6032 & 88.9202 \\
\hline
\end{tabular}

\subsection{Compressive Strength of the Formed Clinkers}

The compressive strength of the various prepared Portland cement clinkers containing PFa (F0-F5) is plotted as a function of hydration periods from 1 day up to 90 days in Figure 6 . The results indicated that the values of compressive strength for all hardened cement pastes at any age of hydration are much near or close to each other so that it can be said that they are the nearly same. This is primarily attributed to the similar composition of $\mathrm{PFa}$ to normal cement $[16,34,35]$ as shown in Tables 1, 2 and also Figure 4, where even the major cement phases responsible for the cementation properties are near to each other [16, 21, 24, 36, 37]. Also, the blaine surface area or fineness of the various cement clinkers (F0-F5) increased with the addition of $\mathrm{PFa}$ [24, 30, 37]. Moreover, although the cement clinkers containing $\mathrm{PFa}$ are manufactured at lower firing temperatures, they exhibited compressive strength near to that of the blank (F0). As a result, the optimum PFa content would be in between 25 and 35 wt. \%

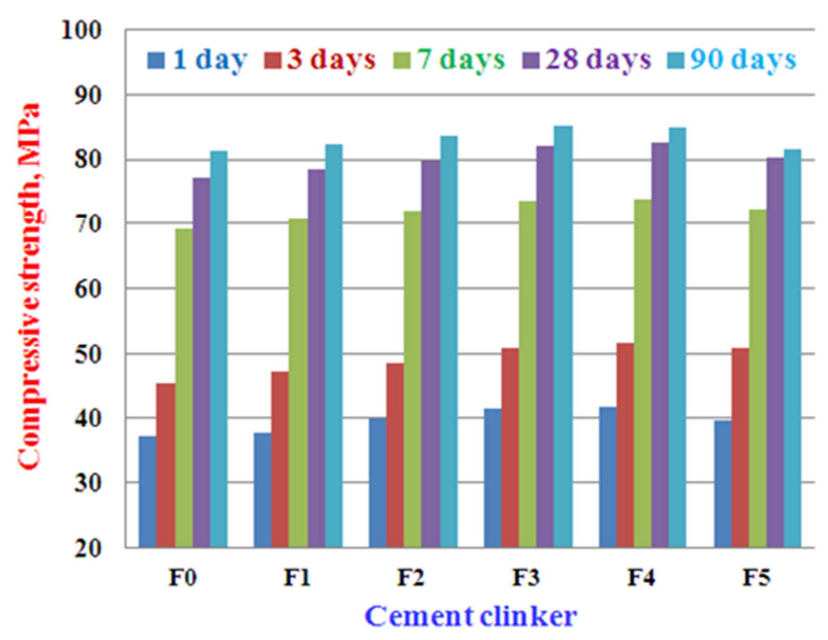

Figure 6. Compressive strength of the prepared Fa cement clinkers.

\section{Conclusion}

The mineralogy and chemical properties of pulverized fly ash (PFA) was studied so as to determine its possibility to use it as a raw material in cement industry. It can be concluded that the oxide composition of the used $\mathrm{PFa}$ sample supplied by a local plant in Egypt can justify or apply as a raw material in the raw meal of Portland cement clinker manufacturing, and the result resulting clinker can gain some important characteristics in its durability. This does not only save expensive natural resources, but also it can save energy as well. The formed major phases in presence of $\mathrm{PFa}$ are more or less the same as those of the blank as experimentally achieved and approved by the compressive strength. As the PFa content increased, the free lime contents decreased and also the firing or clinkering temperature decreased. The optimum PFa content must not exceed than 35 wt.\%. This is essentially attributed to that any further increase resulted in adverse effects on all characteristics of the produced clinker.

\section{Acknowledgements}

Authors wish to express their deep thanks to NRC for helping to obtain materials, processing, preparing, molding and measuring all of the obtained data of the study.

\section{Compliance with Ethical Standards}

The authors declare that they have no competing interests.

\section{References}

[1] Zhang, H.; Hu, J.; Qi, Y.; Li, C.; Chen, J.; Wang, X.; He, J.; Wang, S.; Hao, J.; Zhang, L., Zhang, Y., Li, R; Wang, S.; Chai, F (2017), Emission characterization, environmental impact, and control measure of PM2.5 emitted from agricultural crop residue burning in China. Journal of Cleaner Production, 149: 629-635. https://doi.org/10.1016/j.jclepro.2017.02.092

[2] Olgun A; Erdogan Y; Ayhan Y; Zeybek B (2005), Developments of ceramic tiles from coal fly ash and tincal ore waste, Ceramics International, 31, 1, 153-158. https://doi.org/10.1016/j.ceramint.2004.04.007

[3] Kumar S; Patil CP (2006), Estimation of resource savings due to fly ash utilization in road construction, Resources, Conserv. Recycling, $48,425-140$. https://doi.org/10.1016/j.resconrec.2006.01.002

[4] Majchrzak-Kuceba I; Nowak W (2004), Thermal analysis of fly ash based zeolites, J. Thermal Analysis Calorim, 77, 125131. https://doi.org/10.1023/B:JTAN.0000033195.15101.4e

[5] Moreno N; Querol X; Andrés JM; Stanton K; Towler M; Nugteren H; Janssen-Jurkovicov M; Jones R (2005), Physicochemical characteristics of European pulverized coal combustion fly ashes, Fuel, 84, 1351-1363. https://doi.org/10.1016/j.fuel.2004.06.038

[6] Pacewska B; Blonkowski G; Wilinska I (2008), Studies on the pozzolanic and hydraulic properties of fly ashes in model systems, 94, 1, 2, 469-476. https://doi.org/10.1007/s10973008-9179-8

[7] Pacewska B; Blonkowski G; Wilinska I (2006), Investigations of the influence of different fly ashes on cement hydration, J. Therm. Anal. Cal., 86, 1, 1, 179-186. https://doi.org/10.1007/s10673-005-7136-7

[8] Lee SH; Sakai E; Daimon M; Bang WK (1999), Characterization of fly ash directly collected from electrostatic precipitator, Cem. Concr. Res. 29, 11, 1791-1797. 
[9] Koukouzas NK; RZeng R; Perdikatsis V; Xu W; Kakaras EK 2006), Mineralogy and geochemistry of Greek and Chinese coal fly ash and elemental composition, Fuel, 85, 16, 23012309. https://doi.org/10.1016/j.fuel.2006.02.019

[10] Darweesh, H.H.M. (2012), Setting, hardening and Strength properties of cement pastes with zeolite alone or in combination with slag, InterCeram International (Intern. Cer. Review), Germany, Vol. 1, 2012, 52-57.

[11] Ramamurthy K; Harikrishnan KI (2006), Influence of binders on properties of sintered fly ash aggregate, Cem. Concr. Compos., 28, 33-38. https://doi.org/10.1016/j.cemconcomp.2005.06.005

[12] Canpolat F; Yilmaz K; Kose MM; Sumer M: Yurdusev MA (2004), Use of zeolite, coal bottom ash and fly ash as replacement materials in cement production, Cem. Concr. Res., 34, 5, 731-735. https://doi.org/10.1016/S00088846(03)00063-2

[13] Li B; Liang W; He Z (2002), Study on high-strength composite portland cement with a larger amount of industrial wastes, Cem. Concr. Res., 32, 8, 1341-1344. https://doi.org/10.1016/S0008-8846(02)00804-9

[14] Tangpagasit J; Cheerarot R; Jaturapitakkul C; Kiattikomol K (2005), Packing effect and pozzolanic reaction of fly ash in mortar, Cement Concrete Res., 35, 1145-1151. https://doi.org/10.1016/j.cemconres.2004.09.030

[15] Blanco F; Garcia MP; JAyala J; Mayoral G; Garcia MA (2006), The effect of mechanically and chemically activated fly ashes on mortar properties, Fuel, 85, 2018-2026. https://doi.org/10.1016/j.fuel.2006.03.031

[16] Darweesh, HHM (2005), Effect of the combination of some pozzolanic wastes on the properties of Portland cement pastes, iiC L'industria italiana del Cemento, Italy, 808, 298-311.

[17] Darweesh, HHM (2017), Mortar Composites Based on Industrial Wastes, Intern. J. of Mater. Lifetime, 3, 1, 1-8. DOI:10.12691/ijml-3-1-1.

[18] Fan WJ; Wang XY; Park KP (2015), Evaluation of the Chemical and Mechanical Properties of Hardening High Calcium Fly Ash Blended Concrete, Materials, 8, 59335952 .

[19] Mukherjee MK; Hegde SB; Somani AR (2002), Burnability improvement and raw mix optimization by addition of fly ash, Zem. Kalk Gips, 55, 2, 6-69.

[20] Komljenovi M; Petrašinović-Stoikanović Li; Baščarevi Z; Jovanović Rosić N (2009), Fly ash as the potential raw mixture component for Portland cement clinker synthesis, Journal of Thermal Analysis and Calorimetry, 96, 2, 363-368. https://doi.org/10.1007/s10973-008-8951-0

[21] Taylor, TFW (1997), Cement Chemistry, Academic Press Ltd., London, ( $2^{\text {nd }}$ ed.) Google Scholar

[22] Darweesh, HHM; Abo-El-Suoud MR (2015), Quaternary cement composites from industrial byproducts to avoid the environmental pollution, J. EC-Chemistry, 2, 1, 78-91.
[23] Darweesh, HHM (2013), Hydration, Strength Development and Sulphate Attack of Some Cement Composites, World Applied Sciences Journal, 23 (2): 137-144. ISSN: 1818-4952,

[24] Hewlett PC; Liska M (2017), Lea's Chemistry of Cement and Concrete, $5^{\text {th }}$ ed., Edward Arnold Ltd., London, England. Google Scholar

[25] Wu K; ShiH; Guo X (2011), Utilization of municipal solid waste incineration fly ash for sulfoaluminate cement clinker production. Waste Manage, 31:2001-2008. https://doi.org/10.1016/j.wasman.2011.04.022

[26] ASTM- Standards-C114-77 (1978), Standard methods for chemical analysis of hydraulic cement, 87-127.

[27] ASTM Standards, C618-05 (2005), Standard Specification for coal fly ash and raw or calcined natural pozzolan for use in concrete.

[28] Darweesh HHM; Youssef H (2014), Preparation of 11- !Alsubstituted Tobermorite from Egyptian Trachyte Rock and its Effect on the Specific Propertiesof Portland Cement, InterCeram International (Int. Ceram. Review), 07-08, 358362. https://doi.org/10.1007/BF03401084

[29] ASTM-Standards, C170-90 (1993), Standard Test Method for Compressive Strength of Dimension Stone, 828-830.

[30] Bhatty JI; Gajda J; Miller FM (2003), Commercial Demonstration of High-Carbon Fly Ash Technology in Cement Manufacturing, Intern. ash utilization Symp.

[31] Darweesh HHM (2020), Characteristics of Portland Cement Pastes Blended with Silica Nanoparticles, To Chemistry Journal, 5, 1-14. http://purkh.com/index.php/tochem

[32] El-Didamony $\mathrm{H}$; Radwan A; Khattab I; El-Alfi SA; Mohammed MS (2014), Characteristics of sulphate resistant cement pastes containing different ratios of belite cement phase", Journal of Engineering And Technology Research 2, 4, 52-62.

[33] Abd-El-Aziz MA; Heikal M (2009), Characteristics and durability of cements containing fly ash and limestone subjected to Carons's lake water", Advances in Cement $\begin{array}{lll}\text { Research } & 21 & \text { (3), }\end{array}$ https://doi.org/10.1680/adcr.2007.00025

[34] Abd-El-Aziz MA; Heikal M (2013), Behavior of composite cement pastes containing micro silica and fly ash at elevated temperatures, Advances in Cement Research 21 (3), 91-99. https://doi.org/10.1680/adcr.2007.00025

[35] El-Didamony H; Heikal M; Shoaib M (2000), Homra pozzolanic cement, Silic Ind 65 (3- 4, 39-43.

[36] El-Didamony H; Darweesh HHM; Mostafa RA (2008), Characteristics of pozzolanic cement pastes Part I: Physicomechanical properties" Sil. Ind. (Cer. Sci. \& Techn.), Belgium, 73, Nr. 11-12, 193-200.

[37] Darweesh HHM (2017), Geopolymer cements from slag, fly ash and silica fume activated with sodium hydroxide and water glass, Interceram International", 6, 1, 226-231. https://doi.org/10.1007/BF03401216 